\title{
The Mediating Role of Entrepreneurial Self-Efficacy And Risk Preference on The Relationship Between Entrepreneurship Education And Entrepreneurial Career Option: A Conceptual Perspective
}

\author{
YakubuAbdullahiYarima ${ }^{1,}$ Dr.Norashidah Bint Hashim ${ }^{2}$ \\ ${ }^{2}$ Deputy Director, CEDI Universiti Utara Malaysia \\ ${ }^{1}$ Universiti Utara Malaysia
}

\begin{abstract}
The relationship between entrepreneurship education and entrepreneurial intention has established by several researches, but there are inconsistencies in the findings. Many studies highlight the importance of entrepreneurship education in promoting entrepreneurial intention among graduates. In contrary, numerous studies reported a negative and significant relationship between the two constructs. This conceptual paper maintained that graduate with entrepreneurship training are most likely to become entrepreneur. It is also maintained that graduate with entrepreneurship training might not necessary become entrepreneur unless he/she possesses entrepreneurial self-confidence and risk preference for entrepreneurial career. The study provides assumptions that helps in future studies and makes suggestion for future research.
\end{abstract}

Keywords: Entrepreneurship education, entrepreneurial career option, entrepreneurial self-efficacy, risk preference.

\section{Introduction}

Entrepreneurial career has become more important than ever in recent years, and it has received attention as a leading factor in achieving economic growth, high employment, strong job creation, and positive social development (Ethugala, 2011; Kelley, Singer, \& Herrington, 2012). In addition, the determinants of entrepreneurial career choice are widely researched (Parker, 2009; Sesen\& Pruett, 2014; Smith, \& Beasley, 2011). However, policy makers are particularly interested on the effect of entrepreneurship education on entrepreneurial career, since it can be influenced by policy measures (European Commission, 2003). Consequently, over the past decade there has been a significant increase in entrepreneurship programs globally aimed at increasing entrepreneurial activity at all levels. Karimi, Chizari, Biemans and Mulder (2010) suggest that participation in taught entrepreneurship education can have a positive impact on attitudes towards entrepreneurship as career option.

In this regard, the educational system plays an important role in developing entrepreneurial skills, competencies and attitudes in several ways which in turn stimulates future entrepreneurial career choice. Similarly, entrepreneurship education is considered as the most effective means of embedding an entrepreneurial culture in higher educational institutions (HEIs) by fostering students' entrepreneurial selfconfidence and developing the supply of future graduate entrepreneurs (Jones, Miller, Jones, Packham, Pickenell, \&Zbierowski, 2011; Sesen, 2013). However, Ogundeji (2014) identified entrepreneurial self-efficacy as the major driving factor stimulating entrepreneurial career among graduates; hence need to be carefully considered in entrepreneurial training.

Therefore, the aim of this paper is to provide a conceptual analysis of mediating effect of entrepreneurial self-efficacy on the relationship between entrepreneurship education and entrepreneurial career choice among university graduates. However, the paper reviews literature on previous work in relation to entrepreneurship education, entrepreneurial self-confidence and entrepreneur career to develop a conceptual framework that indicates the significant relationship between these constructs. Finally, the paper discusses the theoretical background of the study and makes suggestions for future research.

\subsection{Entrepreneurship Education}

\section{Literature Review}

Neck and Greene (2011) view entrepreneurship education as series of activities which aims to enable an individual to assimilate and develop knowledge, skills, values and understanding which allow a broad range of problems to be defined, analysed and solved. Whilst, according to Chang and Rieple (2013) entrepreneurship education aims to develop students' mind-sets, behaviors, skills and capabilities, which will create the entrepreneurs of the future. It has developed as a result of a belief that entrepreneurship can, and should, be taught (Chang \&Rieple, 2013; Fiet, 2000; Henry, Hill, \& Leitch, 2005), rather than predestined by genes, as some have advocated (Baumol, 1983; Katz, 1981; Kuratko, 2005). 
Many studies highlight the importance of entrepreneurship education in promoting entrepreneurial career among graduates (Draycott and Rae, 2011; Gibb, Haskins \& Robertson, 2009; Lourenc ,o\&Jayawarna, 2011). Therefore, considerable academic efforts have been focused upon entrepreneurship education in recent years helping the field to develop and to gain momentum (Giacomin, Janssen, Pruett, Shinnar, Llopis\& Toney, 2011; Gibb, 2011; Goksel\&Aydintan, 2011; Jones, 2010; Matlay, 2010; Nabi, Holden \& Walmsley, 2006; Volkmann, Wilson, Mariotti, Rabuzzi, Vyakarnam\& Sepulveda, 2009).

\subsection{Entrepreneurial Career Option}

According to Moriano, Gorgievski, Laguna, Stephan and Zarafshani (2012) entrepreneurial career option is a conscious and precise decision made for preference of entrepreneurship as career. Entrepreneurial career is consequently seen as a mental process that orients the individual's decision to become an entrepreneur (Boyd \&Vozikis, 1994; Gupta \&Bhawe, 2007).Liñán (2008) seen decision to become an entrepreneur depends on individuals' personal attitude, their perceived control over the firm-creation behaviour, and the perceived social pressure to become (or not) an entrepreneur. Whilst, Awang, Ibrahim andAyub (2013) entrepreneurial career decision depends on individual's beliefs that performing the behaviour will result in desirable outcomes.

Student's entrepreneurial career decision is often to be influenced by a variety of factors such as the dynamic career world, personal attributes, characteristics of individual career option, financial aspects, education-related factors, family background and role models (Douglas \& Fitzsimmons, 2008;Liñán\& Chen 2009; Liñán, Rodríguez-Cohard, \& Rueda-Cantuche, 2011; Kroon \& Meyer, 2001; Von Broembsen, Wood \& Herrington, 2005; Zhang, Duysters\&Cloodt, 2013). In addition, individual personal attributes such entrepreneurial self-efficacy, need for achievement, self-confidence, need for independence and autonomy, are perceived as the major determinants for entrepreneurial career (Douglas, \& Shepherd, 2002; Martinez, Levie, Kelley, Saemundsson\& Schott, 2010). However, entrepreneurship educators should consider how their modules and teaching approach in entrepreneurship may affect students' attitudes and intentions towards entrepreneurial career (Byabashaija\&Katono, 2011; Hussain \&Norashidah, 2015; Kroon \& Meyer, 2001; Morris, Webb, Fu, \&Singhal, 2013; Nieuwenhuizen\& Groenewald, 2008; Potter, 2008).

\subsection{Entrepreneurial Self-Efficacy (ESE)}

Campo (2011) defined ESE as the degree to which one believes that he or she is able to successfully start a new business venture. Whist, Segal, Borgia, and Schoenfeld (2005) and Wilson, Kickul and Marlino (2007) further state that ESE has been demonstrated to play a key role in determining the level of interest in pursuing an entrepreneurial career. ESE is, therefore, viewed as having the capabilities that can modify a person's belief in his or her likelihood of completing the tasks required to successfully initiate and establish a new business venture (Bandura, 1986; Solesvik, 2007; Nabi, Holden \& Walmsley, 2010;Rae \& Woodier-Harris, 2013; Olakitan, 2014). More specifically, entrepreneurial self-efficacy is seen as the degree to which one believes that he or she is able to successfully start a new business venture.

Several studies have established ESE to be a strong driver of entrepreneurial behaviour (Cromie, 2000; Drnovsek, Wniset\&Cardon, 2010; Markman, Balkin\&Baron, 2002; Nwankwo, Kanu, Marire, Balogun\&Uhiara, 2012) and is anticipated to influence individual choices, goals, emotional reactions, effort, ability to cope, and persistence (Gist, Stevens \&Bavetta, 1991). Zhao, Seibert and Hills (2005) and Carr and Sequeira (2007) have indicated that increased self-efficacy yields greater entrepreneurial career intentions. In addition, ESE appears to be an important antecedent of entrepreneurial career (Barbosa, Gerhardt, \&Kickul, 2007; Linan, RodriguezCohard\& Rueda-Cantuche, 2005;Mushtaq, Hunjra, Niazi, Rehman\&Azam, 2011;Pruett, Shinnar, Toney, Llopis\& Fox, 2009; Rae \& Woodier-Harris, 2013; Smith \& Beasley, 2011;Souitaris, Zerbinati\& Al-Laham, 2007; Zhao, etal, 2005).

ESE has been empirically tested and found to associate positively to entrepreneurial career in several studies (Chen, Greene \& Crick, 1998; Douglas and Shepherd, 2002; Krueger, Reilly \&Carsrud, 2000). Higher self-efficacy is associated to entrepreneurship and new venture creation (Frazier \&Niehm, 2006; Krueger \&Brazeal, 1994; Segal, Borgia \&Schoenfeld, 2005). However, individuals with high entrepreneurial selfefficacy ought to have higher degrees of belief that they hold a viable idea for a new business.

\subsection{Risk preference}

Studies established that entrepreneurial eventsarise within high-riskbusiness environments (Bridge, O"Neil\&Cromie, 2003; Kirzner, 1997; Langlois, 2001; Lim, Lubatkin, \& Wiseman, 2010), and suggest entrepreneurs take considerable risks in their activities (Schumpeter, 1934; Casson, 1982; Muller \&Dato-On, 2008). Other studies explored the importance of locus of control to risk taking propensity and entrepreneurial career option (Bandura, 1986; Gómez-Mejía et al., 2007; Muller and Thomas, 2001).

Some researchers argued that risk preferences produce greater control of external risks and that leads to entrepreneurial behaviour (Naldi, Nordqvist, Sjöberg, \&Wiklund, 2007; ).However, other studies establisheda 
strongassociation between entrepreneurial risk preference, innovative ideas, and entrepreneurial career (Astrachan, 2003; Short, Payne, Brigham, Lumpkin, \&Broberg, 2009; Zahra, 2005).Similarly, an increase in entrepreneurial risk preference tends to strengthen the individual's entrepreneurial behaviour(Ozkan, 2011; Ryan \& Wiggins, 2001). Many of these studies call for more research on risk preferences as an important factor forentrepreneurialcareer decision making ( Naldi, et al., 2007; Ozkan, 2011; Zahra, 2005).

\subsection{Entrepreneurial Education and Entrepreneurial Career}

Several studies have been conducted in relation to entrepreneurship education and entrepreneurial career. Among the studies that reported a positive and significant relationship between the two constructs includesLiñán, Urbano and Guerrero (2010); Ellen (2010); Naktiyok, Karabey and Gulluce (2010); Wang, Wei, \& John, 2011; Giacomin, et al., (2011); Iakovleva, Kolvereid and Stephan (2011); Hattab (2014); Engle, Dimitriadi, Gavidia, Schlaegel, Delanoe, Alavarado, He, Buame and Wolff (2010); Rae and Woodier-Harris (2013); Molaei, Zali, Mobaraki and Farsi (2014);Abdulai (2015).

However, studies also reported entrepreneurship education has a negative effect on entrepreneurial intention (Packham, Jones, Miller, Pickernell\&Brychan, 2010;Von Graevenitz, Harhoff\&Weber 2010; Oosterbeek, Van Praag\&IJsselstein 2010;Beynon, Jones, Packham \&Pickernell2014). In addition, other studies revealed the average relationship between entrepreneurship education and entrepreneurial career is ambiguous and cannot be classified as either positive or negative, these includes Acs, Arenius, Hay \&Minniti (2005); Lee, Wong, Foo \& Leung 2011; Souitariset al., (2007); Jones, Jones, Packham and Miller (2008);Parker (2009); Bernhofer and Li (2014). Hence, the above results signify inconsistent findings in relationship between entrepreneurship education and entrepreneurial career.

Furthermore, several studies suggest that entrepreneurship education will only has effects entrepreneurial career if it changes the fundamental attitudes and perceptions of individuals in relation to entrepreneurial career such as; perceived risk preference and entrepreneurial self-confidence (Karimi, et al., 2010; Krueger, et al., 2000; Linan, 2004; Liñán, et al., 2011). However, Hussain and Norashidah (2015) suggest the need of more empirical studies to understand the various factors influencing entrepreneurial career decision in relationship with entrepreneurship education. Similarly, Abdullai (2015) suggests that entrepreneurial ESE should be considered as intervening variable for research into general perceptions of self-employment and more specifically entrepreneurial career. Therefore, in an attempt to bridge in the gap identified the study proposes a model in relationship between entrepreneurship education and entrepreneurial intention using ESE and risk preference as mediating variables.

\section{The Proposed Model}

The model in figure 1 shows the intervention of entrepreneurial self-efficacy and risk preference assumes mediating effect on the relationship between entrepreneurial education and students' entrepreneurial intention. Based on the empirical evidence above, Shapero's Entrepreneurial Event Model (1982) and the Linan's Entrepreneurial Event Model (2004) have been integrated to provide a strong foundation for the model in this study.

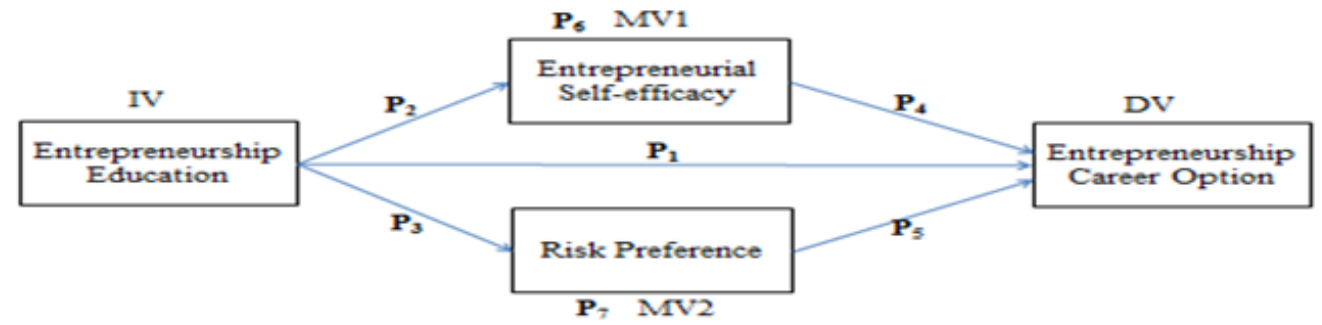

Figure 1: Proposed Research Model of the Study

The research model suggests that participation in entrepreneurship education is outlined as positive 'trigger event' as theorised by Sheparo and Sokol (1982) to be an event that stimulates a change process. Therefore, participation in entrepreneurship education is expected to have direct impact on the students' entrepreneurial career decision at first instant. This means that a relationship exists between entrepreneurship education and students' entrepreneurial career choice. However, it is not always that participation in entrepreneurship education directly influences the students' career decision as the literature reviewed indicated. In such instant, the model suggests the present of entrepreneurial self-efficacy as mediating variable in the relationship between entrepreneurship education and entrepreneurial career option. 
In addition, to investigate the research problem highlighted above the model proposed following prepositions: Preposition 1:Participation inentrepreneurial education has a positive impact on students' entrepreneurialcareer option.

Preposition 2: Participation inentrepreneurial education has a positive impact on students' entrepreneurial selfefficacy.

Preposition 3: Participation in entrepreneurial education has a positive impact on students' risk preference.

Preposition 4: Entrepreneurial self-efficacy has a positive impact on students' entrepreneurial career option.

Preposition 5:Perceived risk preference has a positive impact on students' entrepreneurial career option.

Preposition 6: Entrepreneurial self-efficacy mediates the relationship between entrepreneurial education and entrepreneurial career option.

Preposition 7: perceived risk preference mediates the relationship between EE and entrepreneurial Intention.

\section{Implication Of The Study}

The study could provide useful insights into the state of entrepreneurship education for a range of stakeholders include policy makers, academics, educational institutions and the public in general. More specifically, the study would serve as a feedback for policy makers and other stakeholders on the level of achievement for the new curriculum of entrepreneurship education in relation to entrepreneurial career choice. In addition, the study when empirically tested could provide evidence on mediating effect entrepreneurial selfefficacy and perceived risk preference on the relationship between entrepreneurship education and entrepreneurial career option. Therefore study will offers further validation of previous entrepreneurial career studies and to add to the current literature to facilitate a better understanding of factors influencing the antecedents to entrepreneurial career choice. However, there is need for more empirical researches in this aspect becausereviewed literature highlighted a number of problems associated with entrepreneurship education and entrepreneurial career choice in many nations world over and particular the developing countries (Fayolleat al., 2006; Hattab, 2014; Mc Stay, 2008).

\section{Suggestion For Future Study}

There is need for empirical studies to test the proposed prepositions and the validity of the model. Furthermore, future studies should employ either a cross sectional and/or longitudinal study, so that the direct effect of the independent variables on the dependent variables could be concluded.

\section{References}

[1] Abdulai, A., (2015). Entrepreneurship education and its impact on self-employment intention and entrepreneurial selfefficacy.Humanities and Social Sciences, 3 (1): 57-63.

[2] Acs, Z.J., Arenius, P., Hay, M. \&Minniti, M., (2005). Global Entrepreneurship Monitor.2004 Executive Report, London Business School, Babson, MA.

[3] Astrachan, J. H. (2003). Commentary on the special issue: The emergence of a field. Journal of Business Venturing, 18, 567-573.

[4] Awang, A., Ibrahim, I. I. \&Ayub, S. A. (2013). Determinants of Entrepreneurial Career: Experience of Polytechnic Students. Journal of Entrepreneurship, Business and Economics, 2(1): 21-40

[5] Bandura, A., (1977). Self-efficacy: Toward a Unifying Theory of Behavioural Change. Psychological Review, 84,191-215.

[6] Bandura, A., (1986). Social Foundations of Thought and Action: A social Cognitive. Englewood Cliffs, NJ: Prentice Hall.

[7] Barbosa, S., Gerhardt, M., \&Kickul, J., (2007).The Role of Cognitive Style and Risk preference on Entrepreneurial Self-efficacy and Entrepreneurial Intentions.Journal of Leadership \& Organizational Studies, 13(4): 86-104.

[8] Baumol, W.J., (1983). "Toward operational models of entrepreneurship", in Ronen, J. (Ed.),Entrepreneurship, Lexington Books, Lexington, MA, pp. 29-48.

[9] Bernhofer, L.B. \& Li, J., (2014).Understanding the entrepreneurial intention of Chinese Students. Journal of Entrepreneurship in Emerging Economies, 6 (1): $21-30$.

[10] Beynon, M. J., Jones, P., Packham, G. \&Pickernell, D., (2014)."Investigating the motivation for enterprise education: a CaRBS based exposition". International Journal of Entrepreneurial Behaviour \& Research, 20 (6): 584 - 612.

[11] Boyd, N.G. and Vozikis, G.S., (1994). "The Influence of self-efficacy on the development of entrepreneurial intentions and actions", Entrepreneurship Theory and Practice, 18(4): 63-77.

[12] Bridge, S., O' Neil, K., \&Cromie, S. (2003). Understanding Enterprise: Entrepreneurship and Small Business, (2nd Ed.), Great Britain:

[13] Palgrave Macmillan.

[14] Byabashaija, W., \&Katono, I. (2011).The impact of college entrepreneurial education on entrepreneurial attitudes and intention to start a business in Uganda.Journal of Developmental Entrepreneurship, 16(1): 127-144.

[15] Carr, J.C. \&Sequeira, J.M., (2007). "Prior family business exposure as intergenerational influence and entrepreneurial intent: a theory of planned behaviour approach". Journal of Business Research, 60(10): 1090-1098.

[16] Casson, M. (1982).The Entrepreneur: An Economic Theory. Oxford: Martin Robertson.

[17] Chang, J. \&Rieple, A., (2013).Assessing students' entrepreneurial skills development in live projects.Journal of Small Business and Enterprise Development, 20 (1): 225-241.

[18] Chen C.C., Greene P.G. \& Crick, A., (1998). Does entrepreneurial self-efficacy distinguish entrepreneurs from managers? Journal of Business Venturing, 13(4): 295-316.

[19] Cromie, S., (2000).“Assessing entrepreneurial inclinations: some approaches and empirical evidence”. European Journal of Work and Organizational Psychology, 9 (1): 7-30.

[20] Douglas, E \& Fitzsimmons, J. (2008).Individual intentions towards entrepreneurship vs. intrapreneurship. ASGE 
[21] Douglas, E.J. \& Shepherd, D.A., (2002). "Self-employment as a career choice: attitudes, entrepreneurial intentions, and utility maximization", Entrepreneurship Theory andPractice, 26 (3): 81-90.

[22] Draycott, M. \& Rae, D., (2011). "Enterprise education in schools and the role of competency frameworks", International Journal of Entrepreneurial Behaviour \&Research, 17 (2): 127-145.

[23] Drnoviaek, M., Wincent, J. \&Cardon, M.S., (2010). E start-up: developing a multi-dimensional definition, International Journal of Entrepreneurial Behaviour \&Research, 16 (4): 329-348.

[24] Ellen, A. D., (2010). Entrepreneurial Intentions of Business Students in Finland: Implications for Education. Advances in Management, 3(7).

[25] Engle, R., Dimitriadi, N., Gavidia, J., Schlaegel, C., Delanoe, S., Alavarado, I., He, X., Buame, S., \&Wolff, B., (2010). Entrepreneurial intent: A twelve country evaluation of Ajzen's model of planned behaviour. InternationalJournal of Entrepreneurial Behaviour \& Research, 16(1): 35-37.

[26] Ethugala, C. V., (2011). Expectations of the Private and Civil Stakeholders Responsiveness of the State Sector: Tea Industry of Sri Lanka. Journal of APBITM, 1(1): 13-19.

[27] Fayolle, A., Benoit, G. and Narjisse, L.C. (2006). Assessing the Impact of Entrepreneurship Education Programmes: A New Methodology,

[28] Journal of European Industrial Training, 30 (8/9) 701-20

[29] Fiet, J.O., (2000). "The pedagogical side of entrepreneurship theory", Journal of BusinessVenturing, 6 (2): 1-24.

[30] Frazier, B.J. \&Niehm, L.S., (2006). "Predicting the entrepreneurial intentions of non-business majors: a preliminary investigation", paper presented at the USASBE/SBI Conference, Tucson, AZ, January, pp. 14-17.

[31] Giacomin, O., Janssen, F., Pruett, M., Shinnar, R., Llopis, F., \& Toney, B., (2011).Entrepreneurial intentions, motivations and barriers: Differences among American, Asian and European students. International Entrepreneurship and Management Journal, 7(2): 219-238.

[32] Gibb, A., (2011). "Concepts into practice: meeting the challenge of development of entrepreneurship educators around an innovative paradigm: the case of the International Entrepreneurship Educators' Programme (IEEP)", International Journal of Entrepreneurial Behaviour \& Research, 17 (2): 146-165.

[33] Gibb, A., Haskins, G. \& Robertson, I., (2009). "Leading the entrepreneurial university: meeting the entrepreneurial development needs of higher education institutions", The National Council for Graduate Entrepreneurship, Birmingham.

[34] Gist, M.E., Stevens, C.K. \&Bavetta, A.G., (1991).Effects of Self-efficacy and Post-training Intervention on the Acquisition and Maintenance of Complex Interpersonal Skill, Personnel Psychology, 44: 837-861.

[35] Goksel, A., \&Aydintan, B., (2011). Gender, business education, family background and personal traits: A multidimensional analysis of their effects on entrepreneurial propensity: Findings from Turkey. International Journal of Business and Social Science, 2 (13): 35-48.

[36] Hattab, H.W., (2014). Impact of Entrepreneurship Education on Entrepreneurial Intentions of University Students in Egypt, The Journal of Entrepreneurship 23(1): 1-18.

[37] Henry C., Hill, F., \& Leitch C., (2005). Entrepreneurship education and training: Can entrepreneurship be taught? Part I. Education \& Training, 47 (2/3): 98-112.

[38] Hussain, A., \&Norashidah, B.H., (2015). Impact of Entrepreneurial Education on Entrepreneurial Intentions of Pakistani Students.Journal of Entrepreneurship and Business Innovation, 2(1): 43-53.

[39] Iakovleva, T., Kolvereid, L., \& Stephan, U., 2011.Entrepreneurial intentions in developing and developed countries.Education + Training, 53(5): 353-370.

[40] Jones, C., (2010). "Entrepreneurship education: revisiting our role and its purpose", Journal of Small Business and Enterprise Development, 17 (4): 500-513.

[41] Jones, P. Miller, C., Jones, A. Packham, G., Pickenell, D. \&Zbierowski, P., (2011).Attitudes and motivations of Polish students towards entrepreneurial activity.Education $p$ Training, 53(5): 416-432.

[42] Jones, P., Jones, A., Packham, G. \& Miller, C., (2008). "Student attitudes towards enterpriseeducation in Poland: a positive impact", Education p Training,50 (7): 597-614.

[43] Karimi, S.; Chizari; Biemans, H. J. A. \& Mulder M., (2010). Entrepreneurship Educationin Iranian Higher Education: The Current State and Challenges. EuropeanJournal of Scientific Research, 48 (1): 35-50.

[44] Katz, A.H., (1981). "Self-help and mutual aid: an emerging social movement?",Annual Review of Sociology, 7, 129-55.

[45] Kelley, D.J., Singer, S. \& Herrington, M.D., (2012). "The 2011 Global Entrepreneurship Monitor Report", available at: www.gemconsortium.org/docs/2201/gem-2011-global-report (accessed 25 January 2012).

[46] Kirzner, I.M. (1997). "Entrepreneurial Discovery and the Competitive Market Process: An Austrian Approach." Journal of Economic

[47] Literature 35 (1), 60-85.

[48] Kroon, J. \& Meyer, S. (2001). The role of entrepreneurship education in career expectations of students.South African Journal of Higher Education, 15 (1): 47-53.

[49] Krueger, N.F. \&Brazeal, D.V., (1994). Entrepreneurial potential and potential entrepreneurs, Entrepreneurship Theory and Practice, 19(3): 91-104.

[50] Krueger Jr, N. F., Reilly, M. D., \&Carsrud, A. L., (2000).Competing models of entrepreneurial intentions.Journal of business venturing, 15(5): 411-432.

[51] Kuratko, D.F., (2005). The Emergence of Entrepreneurship Education: Development, Trends and Challenges, Entrepreneurship Theory and Practice, 29 (5): 577-597.

[52] Langlois, R. N. (2001). "Knowledge, Consumption and Endogenous Growth.”Journal of Evolutionary Economics 11, 77-93.

[53] Lee, L., Wong, P. K., Foo, M. D., \& Leung, A., (2011). Entrepreneurial intentions: The Influence of Organizational and Individual Factors. Journal of business Venturing, 26(1): 124-136.

[54] Liñán, F., (2008). Skill and value perceptions: how do they affect entrepreneurial intentions? International Entrepreneurship and Management Journal 4:257-272 DOI 10.1007/s11365-008-0093-0

[55] Liñán, F., \& Chen, Y. W. (2009).Development and Cross-Cultural application of a specific instrument to measure entrepreneurial intentions. Entrepreneurship Theory and Practice, 33(3): 593-617

[56] Linan, F., Rodriguez-Cohard, J., \& Rueda-Cantuche, J.M., (2005).Factors affecting entrepreneurial intention levels.Paper presented in the Forty-fifth Congress of the European Regional Science Association, Amsterdam, August, 23-27.

[57] Liñán, F., Urbano, D., \& Guerrero, M., (2010). Regional variations in entrepreneurial cognitions: Start-up intentions of university students in Spain. Entrepreneurship and Regional Development. 
[58] Liñán, F., Rodríguez-Cohard, J. C., \& Rueda-Cantuche, J. M., (2011). Factors AffectingEntrepreneurial Intention Levels: A Role for Education. International Entrepreneurship and Management Journal, 7(2): 195-218.

[59] Lourenc s, F. \&Jayawarna, D., (2011). "The effect of creativity on post-training outcomes in enterprise education", International Journal of Entrepreneurial Behaviour \&Research, 17 (3): 224-244.

[60] Markman, G.D., Balkin, D.B. \& Baron, R.A., (2002). "Inventors and new venture formation: the effects of general self-efficacy and regretful thinking", Entrepreneurship Theory and Practice, 27 (2): 149-166.

[61] Martinez, A. C., Levie, J., Kelley, D. J., Saemundsson, R. J., \& Schott, T. (2010). Global entrepreneurship monitor special report: a global perspective on entrepreneurship education and training. Global Entrepreneurship Monitor, United States.

[62] Matlay, H., (2010). "Introduction: Contemporary perspectives on entrepreneurship education and training", Journal of Small Business and Enterprise Development, 17 (4): 10-18.

[63] Molaei, R., Zali, M.R., Mobaraki, M.H. \& Farsi, J.Y., (2014)."The impact of entrepreneurial ideas and cognitive style on students entrepreneurial intention", Journal of Entrepreneurship in Emerging Economies, 6 (2): 140 - 162.

[64] Moriano, J. A., Gorgievski, M., Laguna, M., Stephan, U., \&Zarafshani, K. (2012). A cross cultural approach to understanding

[65] entrepreneurialintention. Journal of Career Development, 39, 162-185. doi:10.1177/0894845310384481

[66] Morris, M. H., Webb, J. W., Fu, J., \&Singhal, S. (2013). A Competency-Based Perspective on Entrepreneurship Education: Conceptual and Empirical Insights. Journal of Small Business Management, 51(3): 352-369.

[67] Muller, S.L. and Dato-On, M.C. (2008) Journal of Developmental Entrepreneurship, Vol. 13 (1), 3-20.

[68] Mushtaq, H.A., Hunjra, A.I., Niazi, S.K., Rehman, K., \&Azam, R.I., (2011). Planned behaviour entrepreneurship and intention to create a new venture among young graduates: Management \& Marketing Challenge for the Knowledge Society, 6 (3): $437-456$.

[69] Nabi, G., Holden, R. \& Walmsley, A., (2010). "Entrepreneurial intentions among students: towards a re-focused research agenda", Journal of Small Business and Enterprise Development, 17 (4): 537-551.

[70] Nabi, G., Holden, R. \& Walmsley, A., (2006). "Graduate career-making and business start-up: a literature review", Education $p$ Training, 48 (5): 373-385.

[71] Naktiyok, A., Karabey, C.N. \&Gulluce, A.C., (2010). Entrepreneurial self-efficacy and entrepreneurial intention: the Turkish case. International Entrepreneurial Management Journal, 6, 419-435.

[72] Naldi, L., Nordqvist, M., Sjöberg, K., \&Wiklund, J. (2007).Entrepreneurial orientation, risk-taking and performance in family firms.

[73] Family Business Review, 20, 33-47.

[74] Neck, H.M. \& Greene, P.G., (2011). Entrepreneurship education: known worlds and new frontiers, Journal of Small Business Management, 49 (1): 55-70.

[75] Nieuwenhuizen, C., \& Groenewald, D. (2008). Entrepreneurs' learning preferences: A guide to entrepreneurship education. ActaCommercii, 128-144.

[76] Nwankwo, B.E., Kanu, G.C., Marire, M.I., Balogun, S.K.,\&Uhiara, A.C., (2012). Gender-role Orientation and Self efficacy as correlates of entrepreneurial intention.European Journal of Business and Social Sciences, 1 (6): 09-26.

[77] Ogundeji, R. (2014). MicroSMEs in Nigeria: The Prospects and Challenges. A paper delivered at the 3rd South West Regional Integration

[78] Programme on MicroSMEs Forum, Ado Ekiti, $28^{\text {th }}$ February, 2014.

[79] Olakitan, O.O., (2014). The influence of some personality factors on entrepreneurial intentions. International Journal of Business and Social Science, 5(1): 278- 284.

[80] Oosterbeek, H., Van Praag, M. \&IJsselstein, A., (2010).The impact of entrepreneurship education on entrepreneurship skills and motivation.European Economic Review, 54(3): 442-454.

[81] Ozkan, N. (2011). CEO compensation and firm performance: An empirical investigation of UK panel data. European Financial

[82] Management, 17, 260-285.

[83] Packham, G., Jones, P., Miller, C., Pickernell, D., \&Brychan, T., (2010). Attitudes towards entrepreneurship education: A comparative analysis. Education + Training, 52(8/9): 568-586.

[84] Pruett, M., Shinnar, R., Toney, B., Llopis, F., \& Fox, J., (2009).Explaining entrepreneurial intentions of university students: A cross-cultural study.International Journal of Entrepreneurial Behaviour and Research, 15(6): 571-594.

[85] Rae, D., Penaluna, A. \& Dhaliwal, H., (2011). "Higher education and graduate enterprisein the new era", Graduate Market Trends, Winter, Higher Education Careers Service Unit, Manchester.

[86] Rae, D. \& Woodier-Harris, N. R., (2013). "How does enterprise and entrepreneurship education influence postgraduate students' career intentions in the New Era economy?", Education + Training, 55 (8/9): 926 - 948.

[87] Ryan, H. E., \& Wiggins, R. A. (2001). The influence of firmand manager-specific characteristics on the structure of executive

[88] compensation. Journal of Corporate Finance, 7, 101-123.

[89] Schumpeter, J. A. (1934) "The theory of Economic Development: An inquiry into profits, Capital, Credit, Interest, and the Business

[90] Cycles."Harvard Business Review 25 (1), 217-226.

[91] Segal, G., Borgia, D. \&Schoenfeld, J., (2005).The Motivation to become an Entrepreneur, International Journal of Entrepreneurial Behaviour and Research, 11, 42-57.

[92] Sesen, H., (2013). Personality or environment? A comprehensive study on the entrepreneurial intentions of university students, Education + Training, 55 (7): $624-640$.

[93] Sesen, H. and Pruett, M. (2014). The impact of education, economy and culture on entrepreneurial motives, barrier sand intentions: A comparative study of the United States and Turkey. The Journal of Entrepreneurship23(2): 231-261

[94] Shapero, A. \&Sokol, L., (1982).The social dimensions of entrepreneurship", in Kent, C.,Sexton, D. and Vesper, K. (Eds), The Encyclopaedia of Entrepreneurship, Prentice Hall, New York, NY, pp. 72-90.

[95] Short, J. C., Payne, G. T, Brigham, K. H., Lumpkin, G. T., \&Broberg, J. C. (2009). Family firms and entrepreneurial orientation in publicly

[96] traded firms. Family Business Review, 22, 9-24.

[97] Smith, K. \& Beasley, M. (2011). "Graduate entrepreneurs: intentions, barriers and solutions", Education + Training, 53 (8/9): 722 740 .

[98] Solesvik, M., (2007). Attitudes towards future career choice: Stavanger Center for Innovation Research, University of Stavanger Norway.

[99] Souitaris, V., Zerbinati, S. \& Al-Laham, A., (2007). "Do entrepreneurship programmes raise entrepreneurial intention of science and engineering students? The effect of learning inspiration and resources", Journal of Business Venturing, 22 (4): $566-591$.

[100] Volkmann, C., Wilson, K.E., Mariotti, S., Rabuzzi, D., Vyakarnam, S. \& Sepulveda, A., (2009). "Educating the next wave of entrepreneurs: unlocking entrepreneurial capabilities to meet the global challenges of the 21 st century", paper presented at the World Economic Forum, Geneva. 
[101] Von Broembsen, M., Wood, E. \& Herrington, M. (2005).Global entrepreneurship monitor.South African Executive Report. Cape Town: UCT. Graduate School of Business.

[102] Von Graevenitz, G., Harhoff, D. \& Weber, R., (2010). The effects of entrepreneurship education.Journal of Economic Behaviour \& Organization, 76(1): 90-112.

[103] Wang, W, L., Wei, M., \& John, K. (2011).Determinants of Entrepreneurial Intention among College Students in China and USA.Journal of Global Entrepreneurial Research, 1(1), 35-44.

[104] Wilson, F., Kickul, J. \&Marlino, D. (2007). Gender, Entrepreneurial Self-Efficacy, and Entrepreneurial Career Intentions: Implications for

[105] Entrepreneurship Education, Entrepreneurship: Theory \& Practice 31 (3), 387-406.

[106] Zahra, S. A. (2005). Entrepreneurial risk-taking in family firms. Family Business Review, 18, 23-40.

[107] Zhang, Y., Duysters, G., \&Cloodt, M. (2013).The role of entrepreneurship education as a predictor of university students' entrepreneurial intention.International Entrepreneurship and Management Journal. 3 (4):14-21.

[108] Zhao, H., Seibert, S. E., \& Hills, G. E., (2005). The Mediating Role of Self-efficacy in the Development of Entrepreneurial Intentions. Journal of Applied Psychology, 90, 1265-1272. 